\title{
A taxonomic study on Phormidium-group (cyanobacteria) based on morphology, pigments, RAPD molecular markers and RFLP analysis of the 16S rRNA gene fragment
}

\author{
Katarzyna A. Palinska, ${ }^{1 *}$, Bernd Deventer ${ }^{2}$, Kamal Hariri $^{1} \&$ Maria Łotocka $^{3}$ \\ ${ }^{1}$ Carl von Ossietzky University of Oldenburg, ICBM, Geomicrobiology, PO Box 2503, 26111 Oldenburg, Germany; \\ *corresponding author e-mail: k.palinska@uni-oldenburg.de, Tel.: +49 441 7983393, Fax: +49 4417983384 \\ ${ }^{2}$ University of Applied Science Bingen, Environmental Protection, 55411 Bingen am Rhein, Germany. \\ ${ }^{3}$ Institute of Oceanology, Polish Academy of Sciences, Powstańców Warszawy 55, PL-81-712 Sopot, Poland
}

\begin{abstract}
Twenty nine Phormidium-like strains, obtained from different culture collections, isolated from different habitats and geographical localities were analyzed morphologically as well as using HPLC, spectrophotometry, RAPD markers (random amplified polymorphic DNA) and RFLP (restriction fragment length polymorphism) of $16 \mathrm{~S}$ rRNA sequences. On the base of cell width, degree of constriction between adjacent cells and cell form three distinct groups were recognized. Group I consisted of strains with the cell width less than $1.5 \mu \mathrm{m}$, elongated with strong constrictions; group II contained majority strains with the cell width between 1.5 and $2.5 \mu \mathrm{m}$, isodiametric and only slight constrictions and the cross walls; group III contained strains with cells more than $2.5 \mu \mathrm{m}$ wide and disc-shaped, without constrictions. In strains investigated here, only eight major carotenoids and three mycosporines occurred. Phormidium-like strains showed remarkable differences in the carotenoid composition. Four main combinations in occurrence of different carotenoids were found. The presence of zeaxanthin and $\beta$-carotene was common to all studied strains. Molecular analysis did not show any correlation between pigment composition of strains and their phylogenetic relationship. However, genetically similar strains were similar in cell size and shape. The observed morphotypic traits by themselves appear to be insufficient for classification because some distant groups also showed similar features. Our results support the notion that the genus Phormidium sensu Gomont represents a phylogenetically polyphyletic group.

Furthermore, our data have demonstrated the need for a comprehensive revision of the taxonomy of this group. Results of our studies show that the taxonomic problems of the filamentous cyanobacteria with narrow trichomes can be solved only with the application of modern, combined criteria.
\end{abstract}

Key words: Carotenoids, chemosystematics, cyanobacteria, Phormidium, phylogeny, RAPD, RFLP

\section{Introduction}

Genus Phormidium Kützing ex Gomont 1843 is characterized in the botanical literature on the basis of morphological features such as thin, hyaline, partly diffluent or completely dissolved sheaths, which cause filaments to stick together in mat-like layers. It included a large number of species from freshwater and marine environments, with different cell sizes and proportions, different apical cells and different degrees of constrictions at crosswalls. For the Oscillatoriacean cyanobacteria, including genus Phormidium, starting point source is Maurice Gomont's Monographie des Oscillatoriees (1892). Gomont's classification monograph was followed with some modifications by GEITLER (1932), FrÉMY (1934) and DESIKACHARY (1959). The criteria prescribed traditionally for classification of genera in Oscillatoriaceae relied on the quality of external sheaths and colony formation which left considerable free space for interpretations and translations errors, and opened the possibility that some species may have been described in more then one genus. It is therefore possible that Phormidium, as defined in classical literature in fact contains more than one generic entity.

The traditional genera-complex Oscillatoria/Phormidium/Plectonema and Lyngbya was incorporated by RIPPKA et al. (1979) into the "LPP-group", which contained strains with thin trichomes of problematic taxonomy. The 
currenteditionoftheBergey'sManualofSystematic Bacteriology (CASTENHOLZ 2001) includes compiled information from both bacteriological (RIPPKA et al. 1979) and phycological sources (GeITLER 1932). A major revision of LPP-group was introduced by ANAGNOSTIDIS \& KOMÁREK (1988) and KomÁreK \& Anagnostidis (2005) by introduction of new criteria such as cell proportions and division patterns, motility and way of trichome disintegration. Leptolyngbya and Geitlerinema were created as new genera/subgenera to include a large number of oscillatorialean species with trichomes up to $3 \mu \mathrm{m}$ wide.

Diversity of Cyanobacteria is expressed by their morphological, biochemical, and physiological properties, which enable them to settle and persist in a wide range of habitats. Their structural complexity, unusual for prokaryotes, prompted their taxonomic distinction based on phenotypic, mostly morphological properties. The classification of these metabolically uniform but morphologically complex microorganisms is still confused and needs further investigations and search for new characters which would clearly define taxa, especially at the lower-rank level. Many studies have reported on photosynthetic pigments as a diagnostic tool of the different groups of cyanobacteria (LIAAEN-JENSEN 1979; AAKERMANn et al. 1992; Hirschberg \& CHAMOVITZ 1994; Karsten \& Garcia-Pichel 1996). Chemotaxonomy for strains of the genera Spirulina Turpin ex GOMONT 1892, Oscillatoria VAUChER ex Gomont 1892 and Microcoleus DesmazièRes ex GOMONT 1892 has been successfully described (LIAAEN-JENSEN 1979; AAKERMANN et al. 1992; Karsten \& Garcia-Pichel 1996).

In the present study, we have used traditional, morphological features as well as chemical and molecular parameters to characterize geographically distant isolates as well strains originated from different habitats. Our goal was to characterize the biological diversity contained within the unclearly described taxon Phormidium sensu Gomont and to investigate if pigments, especially carotenoids, used as chemotaxonomic tool could be used as a stable taxonomic criterion. The very important objective of this study was to proof if the "morphotypes" Phormidium with widely differing ecology (fresh water, soil, hot springs, salt marshes, etc) represent morphologically and biochemically coherent group.

\section{Materials and Methods}

Strains and growth conditions. 29 Phormidium-like strains (previously studied also by MARQUARDT \& Palinska 2007 and Palinska \& Marquardt 2008) obtained from various culture collections were grown in artificial seawater ASNIII or freshwater medium BG11 (RIPPKA et al. 1979). Strains originated from different geographical regions as well as from different habitats (see Table 1). All isolates were cultivated under identical conditions at $22^{\circ} \mathrm{C}$ and continuous light provided by cool-white fluorescent lamps $(50 \mu \mathrm{E}$ $\mathrm{m}^{-2} \mathrm{~s}^{-1}$ ). All strains were grown for minimum periods of 3 months under the unchanged culture conditions before the analysis were conducted. Strains affiliation is according to the Culture Collections where they were obtained from.

Morphology. Morphological observations were made using photomicroscope Axiovert and Axioplan, Zeiss equipped with phase-contrast and Nomarski optics systems and by Scanning Electron Microscopy (SEM, Zeiss) with the sample preparation described previously (PALINSKA et al. 1998). The mean cell size of 100 cells was measured for each strain. The variations in dimensions are provided as: mean \pm standard deviation $(\mathrm{n}=100)$.

Chlorophyll and phycobiliprotein absorption spectra. Exponential-phase cells were used for determination of phycobiliprotein absorption spectra. An aliquot of 2-4 ml culture was centrifuged at $14000 \mathrm{rpm}$ for $5 \mathrm{~min}$ at room temperature. The pellet was suspended in buffer consisting of: $50 \mathrm{mM}$ Tris/ $\mathrm{HCl}(\mathrm{pH}$ 8), $250 \mathrm{mM} \mathrm{NaCl}$ and $10 \mathrm{mM}$ EDTA and the cells were broken ultrasonically. In order to include chlorophyll a peak in the spectrum the broken cell suspension was incubated $30 \mathrm{~min}$ at $28^{\circ}$ with $5 \%$ Triton, and finally centrifuged for $5 \mathrm{~min}$ at $14000 \mathrm{rpm}$ in Eppendorf centrifuge to remove unbroken cells. The absorbance of the supernatant was measured from 400 to $750 \mathrm{~nm}$ at Hitachi U 3000 spectrophotometer.

Complementary chromatic adaptation. Each strain was cultured for three weeks separately under continuous light with fluorescent lamps $\left(50 \mu \mathrm{E} \mathrm{m}^{-2} \cdot \mathrm{s}^{-1}\right)$. Chromatic illumination was provided by red or green plastic filters interposed between the culture vessels and the fluorescent tubes. Phycobiliprotein absorption spectra were then determined spectrophotometrically for each strain as described above.

Carotenoid extraction and characterization. About $20 \mathrm{ml}$ of Phormidium cultures were collected by filtration onto Whatman GF/F glass fiber filters. The frozen filters were homogenized by ultrasonication in ice-cold $90 \%$ acetone, then incubated at $4{ }^{\circ} \mathrm{C}$ for 2 hours, and finally centrifuged for $20 \mathrm{~min}$ at $5{ }^{\circ} \mathrm{C}$ 
and $4000 \mathrm{rpm}$ to remove cellular particle debris. All steps were done under dim light. $500 \mu \mathrm{l}$ of extract was mixed with $500 \mu \mathrm{l} 1 \mathrm{M}$ ammonium acetate prior to injection. After $5 \mathrm{~min}$ mixing and equilibration, $100 \mu \mathrm{l}$ of this solution was injected onto HPLC column. Pigments were separated using the RP-HPLC technique using conditions described by DEVENTER \& Heckman (1996) and Stoń \& Kosakowska (2000). The chromatographic system was equipped with an HP Series 1050 chromatographic pump, an HP 1046 fluorescent detector set at $\square \lambda_{\mathrm{Ex}}=431 \mathrm{~nm}$ and $\lambda_{\mathrm{Em}}$ $=660 \mathrm{~nm}$ to confirm the presence of chloropigments, an HP 1100 diode array detector set at $\lambda=440 \mathrm{~nm}$, and Model 7125 Rheodyne injector with a $100 \mu \mathrm{l}$ loop. Separations were performed on a LiChroCAR ${ }^{\mathrm{TM}}$ LiChrospher $100 \mathrm{RP}-18 \mathrm{e}$ analytical column (particle size: $5 \mu \mathrm{m}$; dimension: $250 \times 4 \mathrm{~mm}$, Merck) after passing through a guard column filled with material identical to the main cartridge. The individual pigments were tentatively identified by their characteristic absorption maxima in a mixture of solvent A (20 methanol: 1M ammonium acetate, $\mathrm{v} / \mathrm{v}$ ) and solvent B (40 methanol : acetone, $\mathrm{v} / \mathrm{v}$ ) corresponding to the appropriate retention time. Evaluation of this identification was done by co-chromatography with commercially available standards. Standards for identification of pigments were either donated generously by Hoffmann-La Roche, Basel, Switzerland or purchased (chl- $a$ from Sigma, ß-carotene from Merck, Germany, myxoxathophyll, zeaxanthin and canthaxanthin and echinenone from The International Agency for ${ }^{14} \mathrm{C}$ Determination DHI Institute for Water and Environment, Denmark). All analyses were conducted in duplicate.

Mycosporine and MAA extraction and characterization. Mycosporines and mycosporine like amino acids (MAAs) extraction and analysis were done essentially as previously described by VOLKMANN et al. (2003). This method allows to extract and separate mycosporines and MAAs deriving from organisms which either live in terrestrial, marine or freshwater habitats.

DNA isolation, PCR amplification, RFLP analyses. DNA was extracted from $25 \mathrm{ml}$ of each culture using protocol of MARQUARDT \& PALINSKA (2007). DNA concentration was measured spectrophotometrically with the help of LabelGuards cuvette (IMPLEN, Germany). Amplification reactions using the $16 \mathrm{~S}$ rDNA cyanobacterial-specific primers PLG of NADEAU et al. (2001), produced a $1.2 \mathrm{~kb}$ fragments. Purified amplification products (PeqLab Biotechnologie, Germany) were used for RFLP analyses. The thermal profile used for amplification included 35 cycles, each consisting of primer extension at $72{ }^{\circ} \mathrm{C}$ for $1 \mathrm{~min}$, denaturation at $94{ }^{\circ} \mathrm{C}$ for $5 \mathrm{~min}$ followed by a final elongation step at $56{ }^{\circ} \mathrm{C}$ for $1 \mathrm{~min}$. Three restriction enzymes: Hae III, Msp I, Alu I were used for the digestion of the PCR-products. The digestion was carried out for $2 \mathrm{~h}$ in the optimum temperature of the enzyme (manufacturer's conditions).

RAPD procedure. For RAPD analysis, one strain was used to test seven 10-base oligonucleotide primers, all with $50 \% \mathrm{GC}$ content and $\mathrm{Tm}=30{ }^{\circ} \mathrm{C}$. One primer with the sequence: GTATGGCCTT, which yielded clear, reproducible, polymorphic bands, was used with the remaining strains. However, prior to amplification of all strains with the chosen primer, the optimization of PCR condition was undertaken. Influence of different concentration of $\mathrm{MgCl}_{2}$, primer, Taq-polymerase and DNA on RAPD banding was tested. The optimal amplification reaction comprised $10 \mathrm{ng} / \mu \mathrm{l}$ of primer combined with $10 \mathrm{x}$ reaction buffer, $2.1 \mathrm{mM} \mathrm{MgCl}_{2}$, $0.2 \mathrm{mM}$ dNTP, 0.05g BSA, 1.75 unit Taq Polymerase (Promega, France), and 125ng template DNA. PCR amplification was performed in a Hybaid T3 thermocycler as follows: initial denaturation at $94{ }^{\circ} \mathrm{C}$ for $5 \mathrm{~min}$, followed by 30 cycles of $94{ }^{\circ} \mathrm{C}$ for $20 \mathrm{~s}, 29$ ${ }^{\circ} \mathrm{C}$ for $30 \mathrm{~s}, 72{ }^{\circ} \mathrm{C}$ for $40 \mathrm{~s}$, and a final extension at 72 ${ }^{\circ} \mathrm{C}$ for $7 \mathrm{~min}$. After amplification, PCR products were electrophoresed through an ethidium bromide-stained $2 \%$ agarose gel

Gel electrophoresis and analyses of banding pattern. The digests as well as PCR products were loaded on to $2 \%$ TAE (40mmol/L Tris, $14.9 \mathrm{mmol}$ acetic acid and 1 mmol/L EDTA, pH 8.0). Metaphor agarose gels were electrophoresed at a constant voltage of $50 \mathrm{~V}$ for $4-6$ h. As a size marker, 100bp ladder was used. Ethidium bromide stained gels were photographed using a gel imaging device (HEROLAB) and the included software, EASY-Image-Plus. The banding patterns were obtained three times in independent experiments starting from new cultures and each repeat was identical. The banding patterns obtained (presence/absence of the band of appropriate size) were analysed visually. Phylogenetic trees were built with the program Treecon (Version 1.3b) software (VAN DE Peer \& De WAchteR 1994). Fischerella PCC 7115 was used as outgroup.

\section{Results}

\section{Morphological observations}

On the base of cell width measurements in all Phormidium-like strains three distinct groups were recognized. Group I consisted of 15 strains with the cell width less than $1.5 \mu \mathrm{m}$, group II contained six strains with the cell width between $1.5-2.5 \mu \mathrm{m}$ and the group III contained eight strains with the widest (more than $2.5 \mu \mathrm{m}$ ) cells (Fig. 1, Table 1). The minimum cell width observed was $0.7 \mu \mathrm{m}(\mathrm{OL}$ 05, O L32, OL S5-C, OL S3-C and OL M10-C) and the maximum was $6.3 \mu \mathrm{m}$ (CCAP 1462/10). 


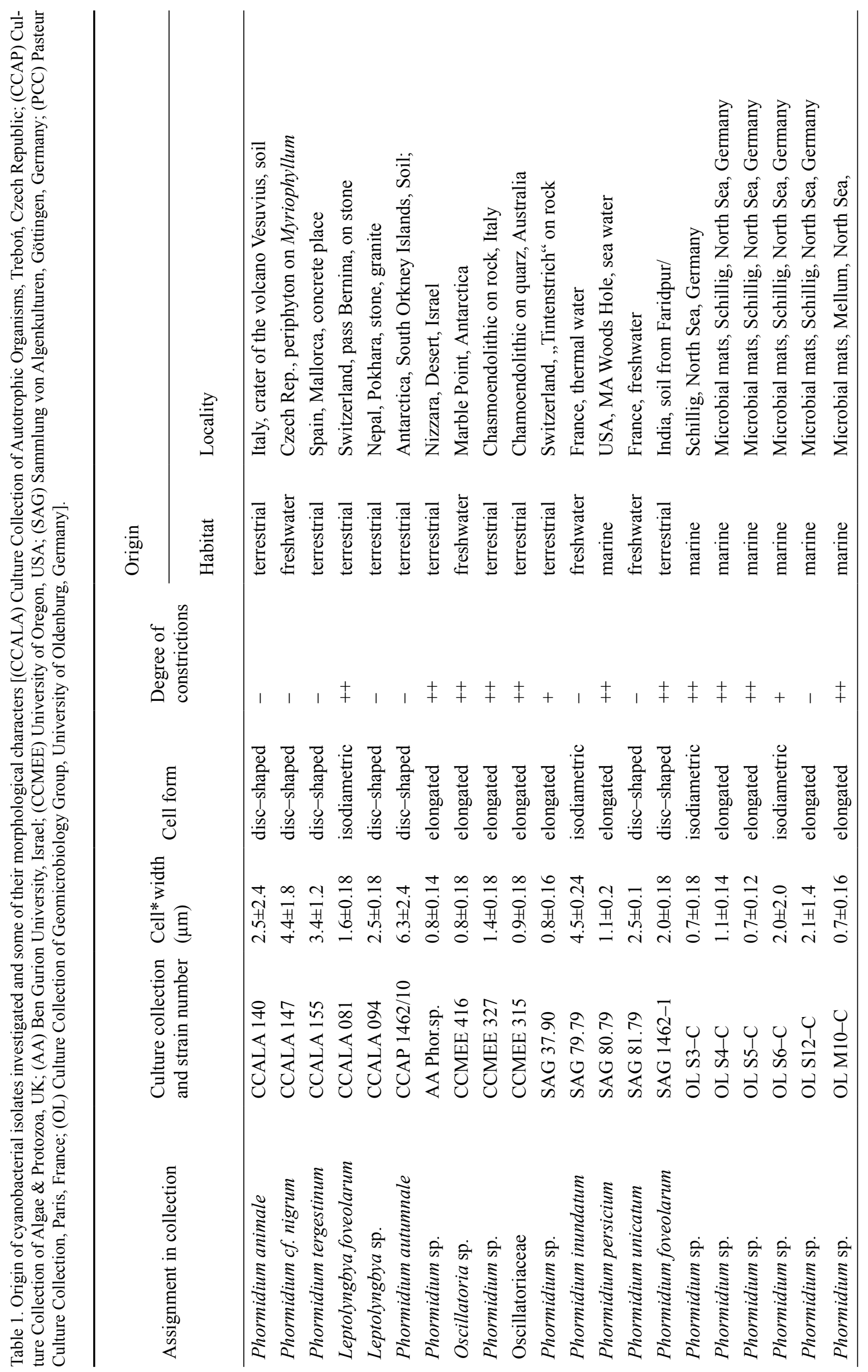




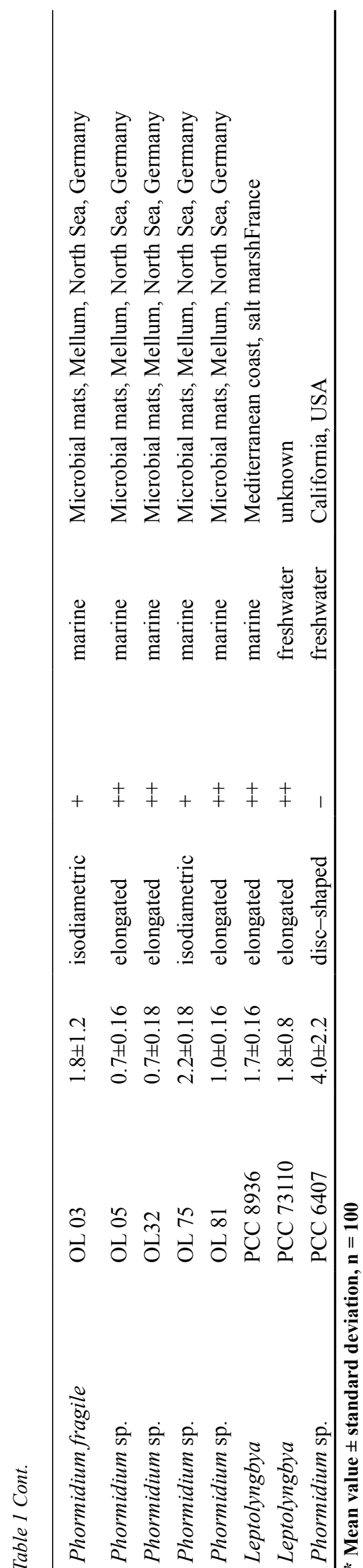

Cells from all the isolates showed different degree of constriction between adjacent cells and cell form varied from disc-shaped (length/diameter $<1)$ through isodiametric (length/diameter $\sim$ ) to elongated (length/diameter $>1$ ) (Fig. 1). Terminal cells from all strains were rounded, without gas vesicles. Calyptra, thick ended cap on the outer cell wall of an apical cell, was only found in one strain, Phormidium autumnale CCAP 1462/10. From eight strains with the cells wider than $2.5 \mu \mathrm{m}$ seven had disc-shaped cell form and one isodiametric. Six strains had cell diameter between 1.5 and $2.5 \mu \mathrm{m}$ and four of them showed isodiametric cell form, one elongated and one disc-shaped. The 14 from all 15 thinnest strains (less than $1.5 \mu \mathrm{m}$ wide) had elongated cells and only one isodiametric. All strains studied were visually proved to be motile. Further phenotypic information about the studied strains are discussed in previous studies (MARQUARD \& PALINSKA 2007; PALINSKa \& MARQUaRdT 2008)

\section{Phycobillin pigment composition and chromatic adaptation}

The 29 Phormidium-like strains contained three types of phycobilin pigment composition (Fig. 2). Most of the strains (23) had a large valley around $550 \mathrm{~nm}$ and a large absorption peak around $630 \mathrm{~nm}$ in the absorption spectrum, which indicated that they contain phycocyanin (PC) but no phycoerythrin (PE). Second type (CCALA 094, CCAP 1462/10, PCC 8936 and SAG 81.79) had a small valley in their absorption spectrum around $550 \mathrm{~nm}$, a relatively large peak at 570 and smaller one at $630 \mathrm{~nm}$. This indicated that they contained both PE and PC and had a low PE:PC ratio. Two of the investigated strain: CCAP 1462/10 and CCALA 094 showed the ability to undergo complementary chromatic adaptation by altering both PC and PE content. When they were grown under red light, the trichome mass colour was pale blue-green with small peak around $570 \mathrm{~nm}$, but a large peak around $630 \mathrm{~nm}$. In contrast, when grown under green light, trichomes became reddishpurple or reddish-brown with a large peak around $570 \mathrm{~nm}$ and small one at $630 \mathrm{~nm}$. Strains of group III (Strain SAG 80.79) contained both PE and PC and had a high PE:PC ratio.

\section{Carotenoids, chlorophyll a and mycosporine}

The results of the carotenoid compositions of all the Phormidium-like strains, which have been analysed, are compiled in Table 2. A uniform 


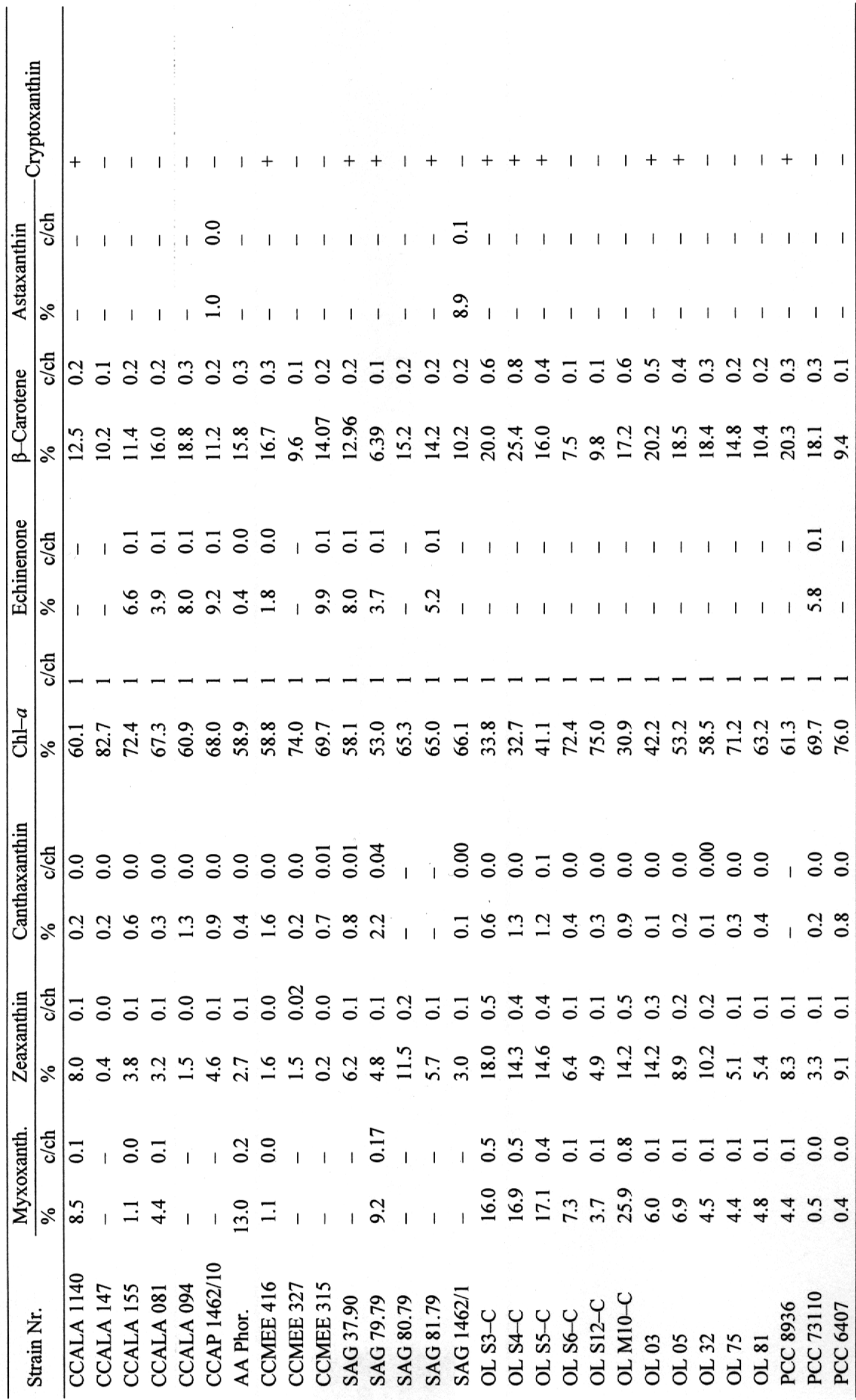


Table 3. Mycosporines identified in studied Phormidium-like strains. Bold printed are main fragments and $\lambda_{\max } \mathrm{UV}$ absorption maxima.

\begin{tabular}{|c|c|c|c|c|c|}
\hline Substance & Ret. time & $\lambda_{\max }$ & $\begin{array}{l}\text { Fragmentation pat- } \\
\text { tern }\end{array}$ & Molecular mass & Strain \\
\hline Mycosporine-glutaminol & 9.5 & 310 & $285,267,235$ & 302.15 & $\begin{array}{l}\text { Leptolyngbya sp. } \\
\text { CCALA } 094\end{array}$ \\
\hline $\begin{array}{l}\text { Mycosporine-glutaminol- } \\
\text { glucoside }\end{array}$ & 10.5 & 310 & $\begin{array}{l}447,429,303,285, \\
267,235\end{array}$ & 464.20 & \multirow{2}{*}{$\begin{array}{l}\text { L. foveolarum } \\
\text { CCALA } 081\end{array}$} \\
\hline $\begin{array}{l}\text { Mycosporine-glutamicol- } \\
\text { glucoside }\end{array}$ & 15.1 & 310 & $\begin{array}{l}448,430,304,286, \\
268,236\end{array}$ & 465,18 & \\
\hline Mycosporine-alanin & 11.3 & 310 & $242,171,147$ & 259.11 & $\begin{array}{l}\text { Oscillatoriaceae } \\
\text { CCMEE } 315\end{array}$ \\
\hline
\end{tabular}

feature of all studied species was the presence of zeaxanthin and $\beta$-carotene. $\beta$-carotene was quantitativelydominantinallstrains. Canthaxanthin was present in all isolates, except in SAG 80.79, SAG 81.79 and PCC 8936. Myxoxanthophyll occurred in 20 and zeaxanthin derivatives in 19 from 29 strains tested. Echinenone was found in 12 strains and cryptoxanthin in only 11 isolates. Asthaxanthin was observed only in two terrestrial strains assigned as $P$. autumnale (C. AGARDH) GoMONT (1892) CCAP 1462/10 and P. foveolarum Montagne ex Gomont (1892) SAG 1462-1. Phormidium-like strains showed remarkable differences in the carotenoid composition. However, four main patterns of occurrence of different carotenoids could be found. The analysis revealed four main combinations:

1. zeaxanthin/ \pm zeaxanthin derivate

2. zeaxanthin/ \pm zeaxanthin derivate/echinenone

3. zeaxanthin/tzeaxanthin derivate/echinenone/ canthaxanthin

4. zeaxanthin/ \pm zeaxanthin derivate/canthaxanthin

All 11 strains isolated from the microbial mats in the North Sea as well as Phormidium animale (C. Agardh ex Gomont) Anagnostidis \& KomÁreK (1988) - strain CCALA 140 had the same carotenoid pattern. In these strains we found all detected carotenoids except echinenone.

In two terrestrial strains: CCMEE 327 and SAG 1462-1 no myxoxanthophyll, zeaxanthin derivatives, echinenone and cryptoxanthin could be detected. The carotenoid pattern in CCMEE 416, the only one strain assigned as Oscillatoria was different from these in Phormidium strains and contained all major carotenoids except astaxanthin. The carotenoid pattern in strain CCMEE 315, assigned only as "Oscilatoriaceae" was similar to other Phormidium-like strains. Interestingly, the molar contain of chlorophyll $a$ highly differ. Maximum chlorophyll $a$ content of $82.7 \%$ was measured in freshwater Phormidium nigrum (Vaucher ex Gomont) Anagnostidis \& KomáreK (1988), strain CCALA 147 and minimum of $30.9 \%$ in marine strain Phormidium sp., OL M10-C. The lowest chlorophyll- $a$ amount was determined in strains isolated from the microbial mats of the North Sea. The molar carotenoid/chlorophyll-a ratios were highly variable from strain to strain, depending on the degree of light adaptation. However, some isolates showed always higher amount of specific pigment compared to other strains. Thus, for example, strains with the lowest chlorophyll- $a$ content (OL S3-C, OL S4-C, OL S5-C, OL M10-C and OL 03) exhibited high content of myxoxanthophyll, zeaxanthin, derivate of zeaxanthin, canthaxanthin and $\beta$-carotene.

Four different mycosporines were identified by their different retention times, absorption maxima and fragmentation patterns. Under the separation conditions all investigated mycosporines have demonstrated different retention times. All information about retention times, UV absorption maxima, fragmentation patterns and calculated exact masses of all UV absorbing compounds are summarized in Table 3. Interestingly, mycosporines were found only in terrestrial strains.

\section{Restriction Fragment Length Polymorphism (RFLP)- analysis}

The PCR reactions gave products of identical length for all Phormidium strains, corresponding to ca. $1200 \mathrm{bp}$. The results of the banding pattern obtained after digestion with three different 


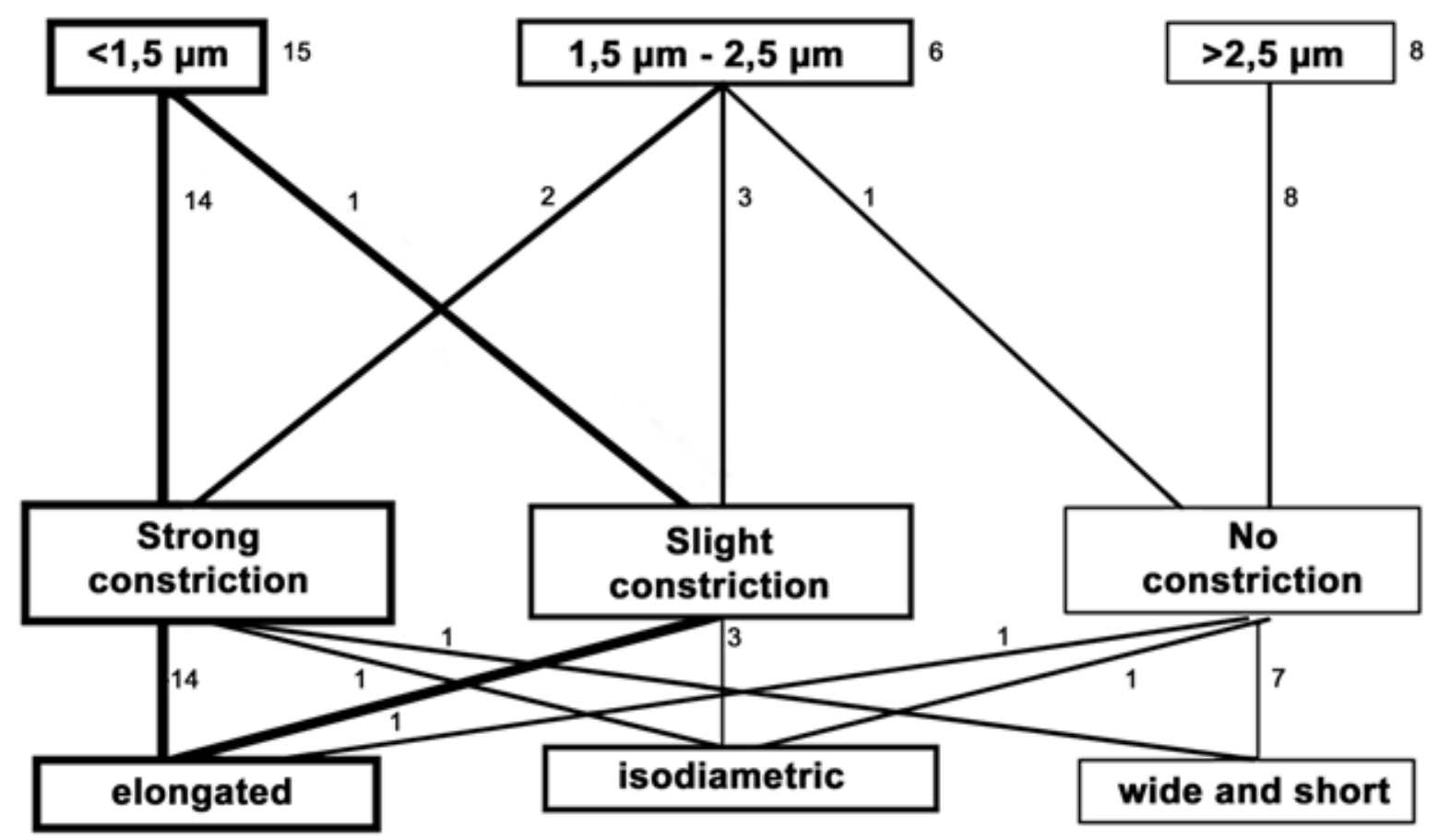

Fig. 1. Three morphological cell types found in studied Phormidium-strains with the data including cell width, form and degree of constriction at the cell-walls: Cells with less than $1.5 \mu \mathrm{m}$ in diameter and strong constrictions at the cross-walls, Cells between $1.5 \mu \mathrm{m}$ and $2.5 \mu \mathrm{m}$ and slight degree of constriction, Cells with more than $2.5 \mu \mathrm{m}$ and no constrictions at the cell-wall. Numbers of strains possessing these characteristics are marked at the right side of each diagram.

restriction enzymes were further analysed with the help of Treecon software. Fig. 3, shows the phylogenetic tree established with AluI restriction enzyme banding patterns. The results of phylogenetic analyses using two other enzymes showed very similar results and therefore are not shown.

On the Fig. 3 four main clusters are visible: A, B, C and D. Cluster A comprise marine strains with the exception of two strain isolated from freshwater in France: SAG 81.79 and SAG 79.79. Cluster D is formed by terrestrial strains. Block 1 consists of strains isolated from one site: Schillig/Germany. Similarly, two strains from Block 2 originate from France and strains from Block 3 were isolated from Mellum/Germany. Additionally, strains OL 03 and OL M10-C had identical banding pattern. Two other strains from Mellum: OL 32 and OL 05 were identical as well.

\section{Random Amplification of Polymorphic DNA (RAPD) study}

A total of 174 bands were generated. The total number of bands per strain ranged from 1 to 10 . A phylogenetic tree (Fig. 4) was constructed in
Treecon, Version $1.3 \mathrm{~b}$ using RAPD bands scored as presence (1) and absence (0) data. All strains tested but PCC 6407 formed three clusters: A, $\mathrm{B}$ and $\mathrm{C}$. Cluster A comprises most of marine strains with the exception of PCC 73110, CCALA 094, AA and CCAP 1462/10. This cluster can be divided into four blocks. In Block 1, 2 and 3 there are marine strains but PCC 73110. Block 4 is formed of strains from extreme habitats: Antarctica, desert in Israel and granite sample from high parts of Nepal. Cluster B consist of terrestrial (CCALA 155, SAG 37.90, CCALA 140, CCMEE 416, CCALA 081 and CCMEE 315) and freshwater strains (SAG 81.79, SAG 79.79 and CCALA 147). Cluster C form three strains: marine isolate $\mathrm{Ol} \mathrm{S12C}$ and terrestrial: CCMEE 327 and SAG 1462-1.

\section{Discussion}

\section{Carotenoids}

Cyanobacteria synthesize the same carotenes as the higher plants, however they produce some unique types of xanthophylls, such as e.g. echinenone. Chemotaxonomy aims at a 
correlation of chemical evidence with systematic classification based on morphological and phylogenetic characters. Although morphological characters have a chemical foundation, chemical characters frequently do not have a morphological expression (LIAAEN-JENSEN 1979).

In the 29 strains investigated here, only eight major carotenoids and three mycosporines occurred. In the review of carotenoids in cyanobacteria, HiRschBerg \& CHAMOvitz (1994) mentioned 15 common cyanobacterial carotenoids. Thus, limited amount of the carotenoids found in the strains studied here, speaks for a certain degree of relatedness among them. The carotenoid analysis of cyanobacterial strains from many genera demonstrated that qualitative carotenoid composition is a suitable biochemical criterion to support classification of cyanobacteria. Often, species from established genera showed the same composition. However, in our studies on Phormidium-like strains exceptions were found. Investigated strains exhibited different carotenoid composition falling into four main carotenoid groups. Here carotenoid composition could be a possible criterion to subdivide species from the genus. Thus, inourinvestigations we couldshow that a uniform feature of all Phormidium-like isolates was the presence of zeaxanthin and $\beta$-carotene. We could also prove that the representative of the genus Oscillatoria (CCMEE 416) differ in their carotenoid pattern from the isolates belonging to the Phormidium-group. We checked two other members of the genus Oscillatoria VAUCHER ex Gomont (1892): Oscillatoria limosa AgardH 1812, strain OL 23 (STAL \& KRUMBein 1985) and Oscillatoria PCC 6506 (RIPPKA \& HeRDMAN 1992). All three Oscillatoria strains exhibited an identical pigment pattern (data not shown). The carotenoid composition as well as morphology and ecology of OL S3-C, OL S4-C and OL S5-C as well as OL M10-C, OL 05 and OL 32 were almost identical. These strains were isolated from the same environment and previous studies using 16S rDNA showed their close phylogenetic relatedness (PFeIFFer \& Palinska 2002; Marquardt \& Palinska 2007). The carotenoid pattern obtained in Phormidium foveolarum and Phormidium persicinum ReInKe ex GoMONT 1892 was compared with the data previously published by FrESNEDO \& SERRA (1992). Unfortunately, we can not confirm these results. It could be possibly due to the misidentification of strains. Phormidium isolates were often misidentified
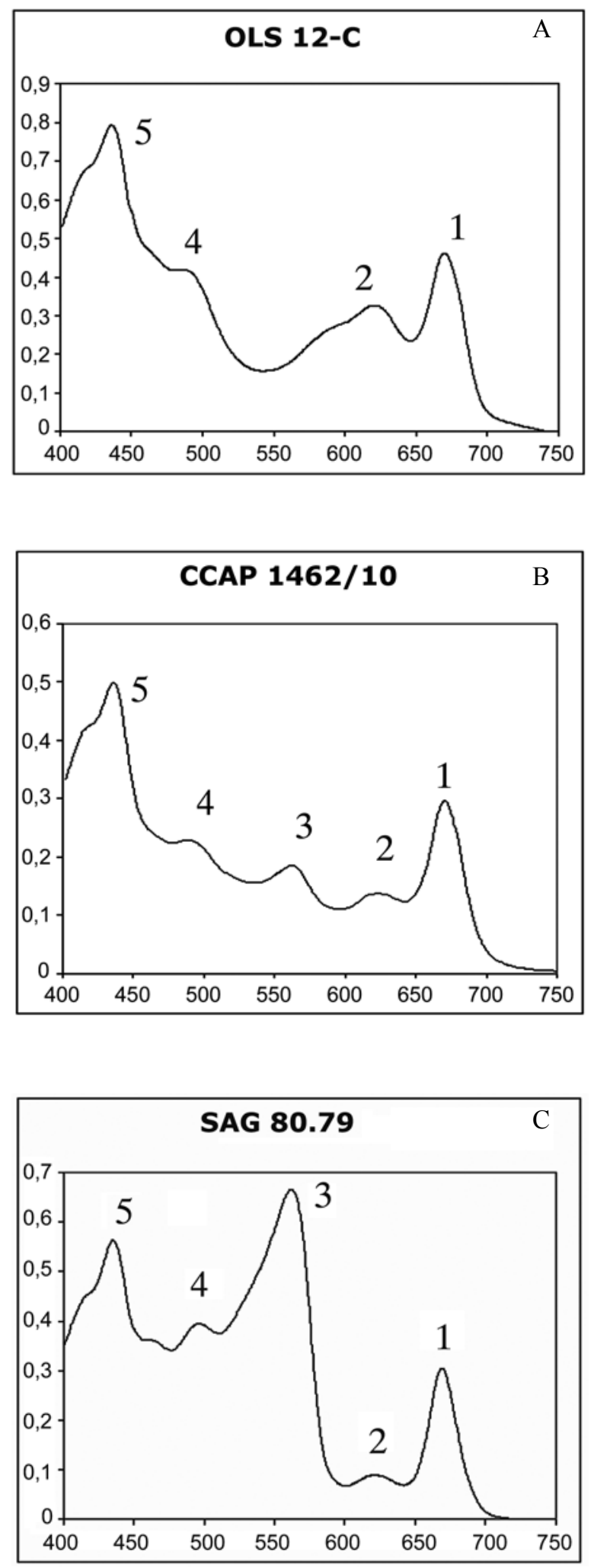

Fig. 2. Three main types of absorption spectra observed in Phormidium-like strains. A) large absorption peak around $620 \mathrm{~nm}$, which indicated presence of phycocyanin (PC) but no phycoerythrin (PE). B) Second type and relatively peaks, respectively, small peak around 570 and large around $630 \mathrm{~nm}$, indicating presence of $\mathrm{PE}$ and $\mathrm{PC}$ and a low PE:PC ratio. C) Strains of group III containing both $\mathrm{PE}$ and PC with a high PE:PC ratio. 1 and $5-$ chlorophyll $a, 2-\mathrm{PC}, 3-\mathrm{PE}$, 4 - carotenoids. 


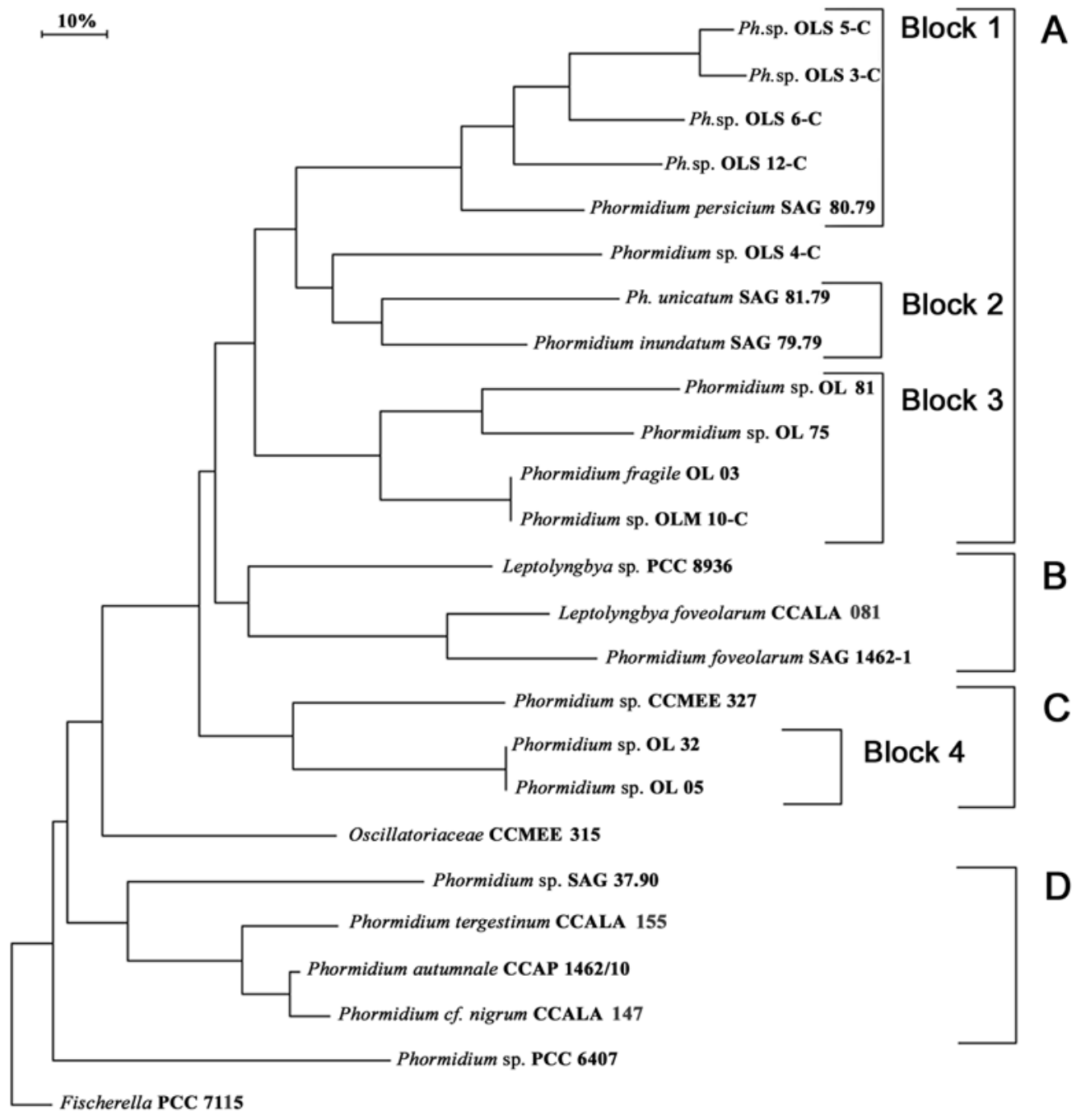

Fig. 3. RFLP dendrogram of $16 \mathrm{~S}$ rRNA gene fragments obtained with the restriction enzyme Alu I. Fischerella PCC 7115 was used as a reference strain.

in the past and present. It makes their study and comparison of data difficult if not impossible. It was our intention to work not only on strains assigned to Phormidium, but also on some isolates assigned to the genera: Leptolyngbya and Oscillatoria. We wanted to prove whether these three genera show remarkable differences in their carotenoids patterns. In course of our studies we succeeded to show that the representatives of the genus Oscillatoria differ in pattern of occurrence of different carotenoids. Strains belonging to genera: Leptolyngbya and Phormidium did not differ significantly.

The presence of myxoxanthophyll could be the critical criterion as the amounts of this carotenoid are strongly light-dependent and may be in some samples below the detection limit although the strain may have the potential for their synthesis. Chlorophyll- $a$ amount in isolates studied here varied significantly, although all strains were cultivated for a period of three month at the same conditions. The percentage of chlorophyll- $a$ in comparison to all pigments differed from $30.9 \%$ to $82.7 \%$. Although, chlorophyll- $a$ amount has traditionally been used as a surrogate measure for cyanobacterial abundance and/or biomass in culture as well as in marine, freshwater and terrestrial habitats (OLIVER \& GANF 2000), our studies show that it responds to laboratory (environmental) conditions such as e.g. light intensity and quality. Thus, chlorophyll $a$ amount is probably not a good indicator of cyanobacterial abundance.

Mycosporine-glutaminol - a mycosporine so far considered to be typical for terrestrial fungi- was also found in terrestrial cyanobacterial 


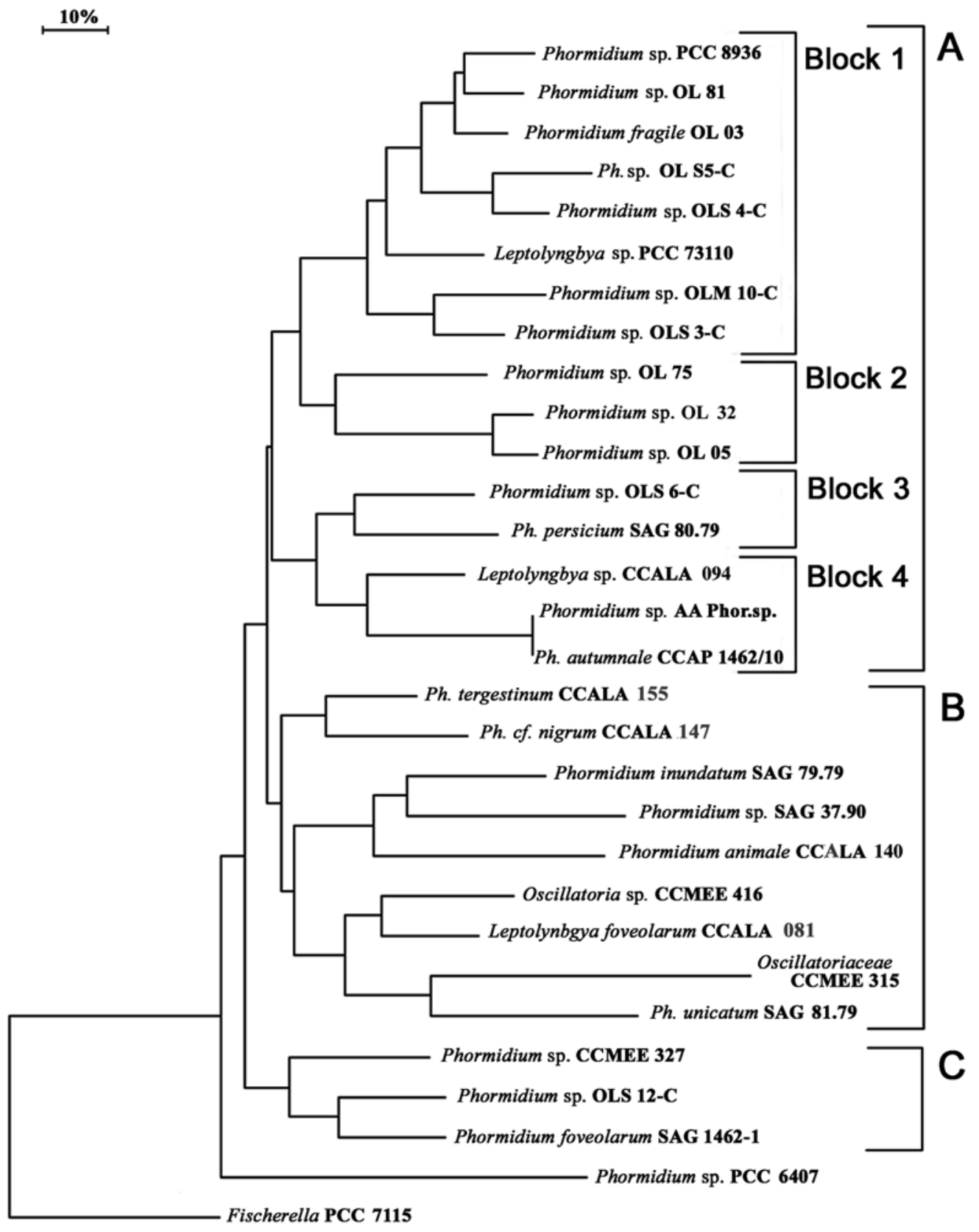

Fig. 4. Dendrogram based on RAPD markers amplified from 29 strains of Phormidium-like group. Genetic distances were calculated and a neighbour-joining tree was constructed with the Treecon (Version 1.3b) software package.

strain - Leptolyngbya sp. ANAGNOSTIDIS et KomÁreK 1988, strain CCALA 094 isolated from granite in Nepal. Leptolyngbya foveolarum ANAGNOSTIDIS et KOMÁREK 1988, strain CCALA 081, from pass Bernina in Switzerland contained the widespread, typical terrestrial mycosporineglutaminol-glucoside and its corresponding free carboxylic acid mycosporine-glutamicolglucoside. Mycosporine-alanin was identified in strain CCMEE 327 assigned to "Oscillatoriaceae", showing chaemoendolithic growth on quartz in Australia. This mycosporine has been described as being of fungal and terrestrial origin playing a role as an inhibitor of conidium germination in Colletotrichum graminicola (LEITE \& NichOLSON 1992). We could recognize this mycosporine as a secondary metabolite of a terrestrial cyanobacterium which function has still to be clarified. Our investigations on Phormidiumstrains from different localities demonstrated that mycosporines exclusively appear in terrestrial isolates (see also VolKMANN \& GorbushinA 2006). Mycosporine like amino acids (MAA) were not detected in any explored strains. We 
are of opinion that mycosporine analysis can be used for the /stinction of material isolated from marine and terrestrial environments. However, not all terrestrial Phormidium-strains contain mycosporines.

\section{RAPD and RFLP data}

Based on our biochemical and molecular findings, it became clear that Phormidium group sensu Gomont represents a species complex, comprised of morphologically similar taxa forming divergent phylogenetic clusters (MARquardt \& PALINSKA 1997), RAPD genotypes, RFLP profiles, and pigment composition (this study). In addition, the wide range of habitats from which Phormidiumlike organisms have been identified and isolated implies that this taxon probably encompasses a number of different genera. When discussing the taxonomy of cyanobacteria, it is essential to explicitly state which species concept is being employed. CASTENHOLZ (1992) advocated a pragmatic species concept, where a species is a cluster of similar strains that have recognizable discontinuities with other known clusters. Further, CASTEnholz \& Waterbury (1989) and Stackebrandt et al. (2002) suggested a polyphasic approach, combining morphological, ultrastructural, biochemical, etc. data sets. COHAN (2001) has proposed that bacterial species could be split into smaller, more meaningful units by incorporating the concept of the ecotype, and that an "ecotype model" could provide a rational basis for demarcating bacterial taxa.

In our study, we could show genetic relationship between Phormidium organisms originating from distinct geographical sites using RAPD analysis and RFLP method. Similar results based on sequences of the 16S rRNA gene and the adjacent intergenic transcribed spacer (ITS) were obtained by Marquardt \& PALINSKa (2007).

When discussing possible phylogenetic relationships between Phormidium strains, one could ask if these strains may have cosmopolitan distribution. KomÁreK \& ANAGNostidis (1999) questioned cosmopolitan distribution of cyanobacteria. They are of opinion that many taxa have more narrowly defined ranges of distribution than previously thought. The present research supports this thesis partly. Comparisons of cyanobacteria in freshwater, marine and terrestrial environments in this and our previous studies (MarqardT \& PalinsKa 2007; PaLINSKa \& MARQUARDT 2008) showed, that the distribution of populations follows patterns that correlate with ecological determinants rather then with the formal morphotypic description of the genus "Phormidium". These results are consistent with similar conclusions derived from the phylogenetic assessment of the formal genus Oscillatoria, which also proved to be polyphyletic (WiLmotte \& HERDMAN 2001). Within a broader genotypic framework, the studied morphotypic characters were subject to nutritional and other environmental impacts, and that changes in environmental conditions modified phenotypes in a predictable fashion at light-microscopic and ultrastructural level (see also MARQARDT \& PALINSKa 2007).

Results based on RAPD and RFLP analysis showed possible relationship between Phormidium organisms from different geographical places. That is why we suggest the hypothesis that Phormidium strains were firstly globally distributed in similar habitats but have later been genetically changed under pressure of different environments. This is also reflected in their morphology and most pronounced in pigment composition. SCHELDEMAN et al. (1999) and CASAMATTA et al. (2003) showed on examples of Arthrospira and Phormidium retzii strains that species of cyanobacteria are more localized than having global distribution.

According to our molecular studies providing phylogenetic background of all strains used here, the pigment analysis data did not correlate with their phylogenetic relationship. Our data show that one should be careful to apply the difference of the pigment composition directly to the classification. Phormidium strains from this study survived under different environments and the adaptation/acclimation strategies are different between different strains. Chemotaxonomic features in case of our studies correlate rather with the environments where the strains where isolated from then with their phylogenetic relationship.

Further, no correlation was found between position of the strains in the phylogenetic tree (MarquardT \& PalinsKa 2007), RAPD and RFLP profiles and their morphology. Structural properties are insufficient in themselves for identification at the genus or species level since some phylogenetically distant members also showed similar morphological traits.

However, genetically similar strains came from similar ecosystems and were similar in cell size and shape (e.g. Bock 1 and 3, Cluster $\mathrm{C}$ on Fig. 4). Nevertheless, these traits are insufficient in themselves for classification since some distantly 
groups showed similar traits.

At that point we should mention that our studies were conducted exclusively on strains obtained from different culture collections. It is known that cultured strains of cyanobacteria often show little similarity to natural populations as some phenotypic traits are apparently not expressed in the culture environment. This problem has led to the misidentification of cultures (PALINSKA et al. 1996; WiLmotte \& Herdman 2001) and can diminish the value of phylogenetic reconstructions and other analyses of evolutionary interrelationships.

Although there is no correlation between geographic origin and phylogeny (with the exception of strains SAG 81.79 and SAG 79.79 isolated in France, Fig. 3), there is a clear relationship between the strains' original environmental habitat and specific subtrees on the phylogenetic trees. Several individual clades restricted to marine, freshwater, or terrestrial strains are to be seen, but these clades themselves have a mixed distribution overall in the inferred trees. For example, all strains of Block 4 are from terrestrial origin. The other clades contain either marine organisms or a mixture of terrestrial and freshwater strains. However, one should remember that all strains from this study of terrestrial origin grow well in freshwater medium. Terrestrial habitats can vary greatly in the amount of available water; e.g. a rock might be moistened regularly by stream or rain water. An example of a strain from an extreme terrestrial habitat is Phormidium sp. AA which comes from the particularly dry Nizzara desert. At first glance it may seem surprising that this strain clusters together with Phormidium autumnale CCAP 1462/10 from Antarctica. However, the ice-free regions of Antarctica are deserts as well. A similar close phylogenetic relationship was found by CASAmatta et al. (2005) for Antarctic Microcoleus acremannii and Microcoleus vaginatus from desert soil. These authors point out that both organisms share a similar habitat that is characterized by long periods of desiccation and high levels of ultraviolet radiation.

Our results indicate that the exclusive use of phenotypic (morphology and pigments) traits to determine a natural system of the cyanobacteria that is based on historical evolutionary relationships is problematic, even more so because phenotypes might change under variable environmental conditions or after extended cultivation.

According to our extensive morphological, biochemical and molecular studies we could show that Phormidium-group is not coherent, needs drastic revision in the future and ultimatively will have to be redefined on the basis of the morphological and genetic properties of type species. It is in agreement with our previous studies where we have used different molecular methods then these used here (MARQUARDT \& Palinska 1997; Palinska \& Marquardt 1998). It is premature, however, to reclassify this group of morphotypes as their genetic relationships are still incomplete. Observations on these morphologically complex cyanobacteria in freshwater, marine and terrestrial environments showed, that the distribution of populations of morphologically complex cyanobacteria follows patterns that correlate rather with ecological determinants then with the organisms determined as "Phormidium".

\section{Acknowledgments}

The German Science Foundation has financially supported this work through the projects DFG Pa $842 / 1-1$ and $842 / 1-3$. The authors wish to thank Marc Volkmann for mycosporine analysis and Alicja Kosakowska for an appreciated opportunity to use analytic equipment of the Biochemical Laboratory (PAN, Sopot).

\section{References}

Aakermann, T., Skulberg, O. M. \& Liahen-Jensen, S. (1992): A comparison of the carotenoids of strains of Oscillatoria and Spirulina (Cyanobacteria). - Bioch. Syst. Ecol. 20: 761769.

Anagnostidis, K. \& KomÁrek, J. (1988): Modern approach to the classification system of cyanophytes, 2 - Oscillatoriales. - Algological Studies 80: 327-472.

Casamatta, D. A, Johansen, J.R., Vis, M.L. \& Broadwater, S.T (2005): Molecular and morphological characterization of ten polar and near-polar strains within the Oscillatoriales (Cyanobacteria). - J. Phycol. 41: 421-438.

Casamatta, D.A., Vis, M.L. \& Sheath R.G. (2003): Cryptic species in cyanobacterial systematics: a case study of Phormidium retzii (Oscillatoriales) using RAPD molecular marker. - Aquat. Bot. 77: 295-309.

Castenholz, R.W. (1992): Species usage, concept and evolution in the cyanobacteria (blue-green algae). - J. Phycol. 28: 737-745.

Castenholz, R. W. (2001): General characteristics 
of Cyanobacteria. - In: Garrity, G. M. (ed.): Bergey's Manual of Systematic Bacteriology, 2nd edition. - pp. 474-78, Springer, New York. Castenholz, R.W., \& Waterbury, J.B. (1989): Group I. Cyanobacteria. - In: Holt, J.G. (ed.): Bergey's manual of systematic bacteriology, vol 3. - pp. 1710-1727, Williams \& Wilkins, Baltimore.

Cohan, F. M. (2001): Bacterial Species and Speciation. - Syst. Biol. 50: 513-524.

Desikachary, T. V. (1959): Cyanophyta. Indian Council Agricultural Research. - 686 pp., Reprinted by Academic Press, New York \& London.

Deventer, B. \& Heckman, C. W. (1996): Effects of prolonged darkness on the relative pigment content of cultured diatoms. - Aquat. Sci. 58: 241-252.

FrÉMY, P. (1934): Cyanophycées des côtes d'Éurope. Mem. de la soc. Nation. des Sci. Nat. et Math. de Cherbourg 41: 1-234.

Fresnedo, O. \& Serra, J. L. (1992): Effect of nitrogen starvation on the biochemistry of Phormidium laminosum. - J. Phycol. 28: 786-793.

Geitler, L. (1932): Cyanophyceae. - In: Rabenhorst Kryptogamen Flora 14. - 1196 pp., Akademischer Verlag, Leipzig

Gomont, M. (1892): Monographie des Oscillariées (Nostocaceae homocystées). - Ann. Sci. Nat. Ser. Bot. 15: 265-368.

Hirschberg, J. \& Chamovitz, D. (1994): Carotenoids in cyanobacteria. In Bryant, D. A. (ed.): The molecular biology of cyanobacteria. - pp. 559579, Kluwer, Dordrecht,

Karsten, U. \& Garcia-Pichel, F. (1996): Carotenoids and mycosporine-like amino acid compounds in members of the genus Microcoleus (Cyanobacteria): A chemosystematic study. System. Appl. Microbiol. 19: 285-294.

KomareK, J. \& Anagnostidis, K. (1999): Cyanoprokaryota. 1. Teil Chroococcales. - In: Ettl, H., Gärtner, G., Heynig, H. \& Mollenhauer, D. (eds): Süsswasserflora von Mitteleuropa. - 548 pp., Gustav Fischer Verlag, Jena.

Komarek, J. \& Anagnostidis, K. (2005): Cyanoprokaryota, 2. Teil Oscillatoriales. In: Büdel, B., Gärtner, G., Krienitz, L., \& Schagerl, M. (eds): Süßwasserflora von Mitteleuropa. - 759 pp. Elsevier, München.

Kützing, T.F. (1849): Species algarum. - 922pp., F.A. Brockhaus, Leipzig.

Leite, B. \& Nicholson, R.L. (1992): Mycosporinealanin: A self-inhibitor of germination from the conidial mucilage of Colletotrichum graminicola. - Exp. Mycol. 16: 76-86.

LiAAEN-JENSEN, S. (1979): Carotenoids - a chemosystematic approach. - Pure Appl. Chem. 51: 661-675.

Marquardt, J. \& Palinska, K.A. (2007): Genotypic and phenotypic variability of Phormidiumlike cyanobacteria from different habitats and geographical sites. - Arch. Microbiol. 187: 397-413

Nadeau T-L., Milbrandt, E.C. \& Castenholz, R.W. (2001): Evolutionary relationships of cultivated Antarctic oscillatorians (Cyanobacteria). - J. Phycol. 37: 650-654.

Oliver, R.L. \& GANF, G.G. (2000): Freshwater blooms. - In: Whitton, B. A. \& Potтs, M. (eds): The ecology of cyanobacteria. - pp. 149-194, Kluwer Academic Press, Netherlands.

Palińska, K. A., Krumbein, W. E. \& Schlemminger, U. (1998): Ultramorphological studies on Spirulina sp. - Bot. Mar. 41:349-355.

Palińska, K.A., Liesack, W., Rhiel, E. \& Krumbein, W.E. (1996): Phenotype variability of identical genotypes: the need for a combined cyanobacterial taxonomy demonstrated on Merismopedia-like isolates. - Arch. Microbiol. 166: 224-233.

Palińska, K.A. \& Marquardt, J. (2008): Conformity between molecular and phenotypic results demonstrated on Phormidium autumnale isolates (cyanobacteria). - Arch. Microbiol. 189: $325-335$

Pfeiffer, C. \& PAlińsKa, K.A. 2002. Characterization of marine Phormidium isolates-conformity between molecular and ecophysiological results. - J. Plant Physiol. 159: 591-598.

RipPKA, R. \& Herdman, M. (1992): Pasteur Culture Collection of cyanobacterial strains in axenic culture. Catalogue \& taxonomic handbook. 103 pp., Institut Pasteur, Paris, France.

Rippka, R., Deruelles, J., Waterbury, J. B., Herdman, M. \& STANIER, R. Y.(1979): Generic assignments, strain histories and properties of pure culture of cyanobacteria. - J. Gen. Microbiol. 111: 1-61.

Scheldeman, P., Baurain, D., Bouhy, R., Scott, M., Muhling, M., Whitton, B.A., Belay, A. \& Wilmotte, A. (1999): Arthrospira (Spirulina) strains from four continents are resolved into only two clusters, based on amplified ribosomal DNA restriction analysis of the internally transcribed spacer. - FEMS Microbiol. Lett. 172: 213-222.

Stackebrandt, E., Frederiksen, W., Garrity, G.M., Grimont, P.A.D., Kampfer, P., Maiden, M.C.J., Nesme, X., Rossello-Mora, R., Swings, J., Truper, H.G., Vauterin, L., Ward, A.C. \& Whitman, W.B. (2002): Report of the ad hoc committee for the re-evaluation of the species definition in bacteriology. - Int. J. Syst. Evol. Microbiol. 52: 1043-1047.

Stal, L.J. \& Krumbein, W.E. (1985): Isolation and characterization of cyanobacteria from a marine microbial mat. - Bot. Mar. 28: 351-365.

Ston, J. \& Kosakowska, A. (2000): Qualitative and 
quantitative analysis of Baltic phytoplankton pigments. - Oceanologia 42: 449-471.

TuRnER, S. (1997): Molecular systematics of oxygenic photosynthetic bacteria. - Pl. Syst. Evol. 11:53-86

VAn de Peer, Y. \& De Wachter, R. (1994): TREECON for Windows: a software package for the construction and drawing of evolutionary trees for the Microsoft Windows environment. Comput. Applic. Biosci .10: 569-570.

Volkmann, M. \& Gorbushina, A.A. (2006): A broadly applicable method for extraction and characterization of mycosporines and mycosporine-like amino acids of terrestrial, marine and freshwater origin. - FEMS Microbiol. Lett. 255: 286-295.

Volkmann, M., Whitehead, K., RÜtters, H., RÜllköter, J. \& GoRbushinA, A.A. (2003): Mycosporine-glutamicol-glucoside: a natural UV-adsorbing secondary methabolite of rock inhabiting microcolonial fungi (MCF). - Mass Spect. 17: 897-902.
Wilmotte, A. \& Herdman, M. (2001): Phylogenetic relationships among the cyanobacteria based on 16S rRNA sequences. In: GARRITY G. M. (ed.) Bergey's Manual of Systematic Bacteriology, 2nd edition. - 487-493 pp, Springer, New York.

(C) Czech Phycological Society (2011)

Recieved Sept 2010

Accepted Dec 2010 